\title{
BioLink
}

Jurnal Biologi Lingkungan, Industri, Kesehatan

Available online http://ojs.uma.ac.id/index.php/biolink

\section{PENGARUH KESEIMBANGAN FOREMILK DAN HINDMILK DENGAN POLA DEFEKASI BAYI YANG MENDAPATKAN ASI EKSKLUSIF DI DESA SUKARENDE}

\section{THE EFFECT OF FOREMILK AND HINDMILK BALANCE WITH BABY DEFECTATION PATTERNS THAT GET EXCLUSIVE BREASTMILK IN SUKARENDE VILLAGE

\author{
Debora Paninsari ${ }^{*}$ dan Eva Latifah Nurhayati ${ }^{2}$
}

1 Prodi S1 Kebidanan, Fakultas Keperawatan dan Kebidanan, Universitas Prima Indonesia, 2Prodi DIII Keperawatan, Fakultas Keperawatan dan Kebidanan, Universitas Prima Indonesia, Indonesia

Diterima : 01-08-2019; Disetujui : 17-12-19: Diterbitkan : 10-02-2020

*Corresponding author: E-mail: thebora_depari@yahoo.com

\begin{abstract}
Abstrak
Ibu yang memberikan ASI secara eksklusif kepada bayinya dari tahun 2011-2015 cenderung mengalami peningkatan. Namun, dalam pemberian ASI masih banyak pehamaman ibu yang kurang tentang foremilk dan hindmilk. Foremilk dan hindmilk berkaitan dengan durasi bayi menyusu, jika belum didapatkan bayi secara seimbang dapat menimbulkan masalah pada pola defekasi bayi khususnya yang berusia 1-6 bulan. Tujuan penelitian ini untuk mengetahui pengaruh keseimbangan foremilk dan hindmilk dengan pola defekasi bayi yang mendapatkan ASI Eksklusif. Desain penelitian secara cross sectional, dengan jumlah sampel sebanyak 30 orang ibu yang memiliki bayi usia 1-6 bulan dan menyusui secara eksklusif. Hasil penelitian didapatkan mayoritas (96,7\%) frekuensi buang air besar bayi 1-8 kali sehari, konsistensi feses lunak (96,7\%) dan feses berwarna kuning (93,3\%). Dari 30 responden sebanyak 53,33\% ibu melakukan keseimbangan foremilk dan hindmilk saat menyusui dan sebanyak 86,66\% bayi memiliki pola defekasi yang normal. Hasil uji chi-square tidak ada pengaruh keseimbangan foremilk dan hindmilk dengan pola defekasi bayi yang mendapatkan ASI eksklusif $\left(\mathrm{p}_{\text {value }}=0,222\right)$ dengan 30 jumlah responden yang diteliti. Hal ini menunjukkan bahwa keseimbangan foremilk dan hindmilk belum berpengaruh terhadap pola defekasi bayi termasuk frekuensi, konsistensi dan warna feses bayi yang mendapatkan ASI eksklusif.
\end{abstract}

Kata Kunci: Foremilk dan Hindmilk, Pola Defekasi, ASI Eksklusif

\section{Abstract}

Mothers who exclusively breastfed their babies from 2011-2015 tended to increase. However, in breastfeeding there are still many maternal understandings that are lacking about foremilk and hindmilk. Foremilk and hindmilk are related to the duration of the baby breastfeeding, if the baby has not been obtained in a balanced manner can cause problems in the pattern of defecation of infants especially those aged 1-6 months. The purpose of study was to determine the effect of foremilk and hindmilk balance with defecation patterns of infants who received exclusive. The study design was cross sectional, with total sample 30 mothers who had infants aged 1-6 months and exclusively. The results showed the majority (96.7\%) frequency of defecation of infants 1-8 times, consistency of soft stool (96.7\%) and yellow stool (93.3\%). Out of 30 respondents $53.33 \%$ of mothers had a balance of foremilk and hindmilk while breastfeeding and $86.66 \%$ of infants had normal defecation patterns. Chi-square test results did not influence the balance of foremilk and hindmilk with the pattern of defecation with 30 respondents surveyed. This shows that the balance of foremilk and hindmilk has not affected the pattern of infant defecation including frequency, consistency and color of feces.

Key Words: Foremilk and Hindmilk, Defecation Pattern, Exclusive Breastfeeding

How to Cite: Paninsari, D. dan Nurhayati, Eva. L. (2020). Pengaruh Keseimbangan Foremilk dan Hindmilk dengan Pola Defekasi Bayi yang Mendapatkan ASI Eksklusif Di Desa Sukarende, BioLink: Jurnal Biologi Lingkungan, Industri dan Kesehatan, Vol.6 (2): Hal. 146-152 
Paninsari, D. dan Nurhayati, Eva. L. Pengaruh Keseimbangan Formilk dan Hindmilk dengan Pola Defekasi Bayi yang Mendapatkan ASI Eksklusif di Desa Sukarende

PENDAHULUAN

World Health Organization (WHO) telah mengkaji lebih dari 3.000 peneliti menunjukkan pemberian ASI selama 6 bulan adalah jangka waktu yang paling optimal untuk pemberian ASI Eksklusif. Menurut United Nations International Children's Emergency Fund (UNICEF), cakupan rata - rata ASI Eksklusif di dunia sebesar 38\% (Warsini et al, 2015).

Dalam profil kesehatan Indonesia sejak 2013 hingga 2017, diklasifikasikan lima mortalitas kematian bayi, salah satunya yakni peluang kematian di usia nol sampai sebelas bulan, yang tercatat (2,4\%). Target SDGs (Sustainable Development Goals) pada tahun 2030 diharapkan mampu mengakhiri kematian bayi dan balita yang dapat dicegah, dengan seluruh negara berusaha menurunkan Angka Kematian Neonatal setidaknya hingga 12 per $1.000 \mathrm{KH}$ (Kemenkes RI, 2017).

Defekasi atau buang air besar (BAB) merupakan suatu proses pengeluaran feses dari dalam rektum, yang terdiri dari bahan yang tidak digunakan lagi dan harus dikeluarkan dari dalam tubuh. Menilai pola defekasi bayi yang mendapatkan ASI eksklusif berarti menilai frekuensi defekasi, konsistensi dan warna feses. Frekuensi BAB (Rochitasari et al, 2011)

Bayi yang mendapatkan ASI secara eksklusif dapat mengalami masalah pada pola defekasinya, termasuk frekuensi buang air besar (BAB), konsistensi feses dan juga warna feses bayi. masalah tersebut dapat terjadi apabila kebutuhan seluruh ASI yang keluar dari payudara ibu tidak didapatkan oleh bayi, hal ini sering disebut dengan masalah keseimbangan foremilk dan hindmilk (West, 2011).

Foremilk merupakan ASI yang pertama kali keluar saat menyusui biasanya menit pertama hingga 3-5 menit yang mengandung laktosa yang tinggi dan protein serta lemak yang rendah. Foremilk membantu memuaskan dahaga pada bayi dan merangsang energi serta perkembangan otak. Hindmilk merupakan ASI yang berbentuk krim dengan kandungan lemak yang tinggi disimpan dalam sel susu dan berfungsi untuk memacu pertumbuhan bayi termasuk otak (Uyan et al, 2009).

Penelitian sebelumnya tentang perilaku ibu menyusui dalam keseimbangan foremilk dan hindmilk menunjukkan bahwa 86,62\% ibu tidak melakukan keseimbangan namun konsistensi feses bayi normal. Hal ini tidak sesuai dengan teoritis yang ada bahwa foremilk dan hindmilk harus seimbang didapatkan oleh bayi setiap kali menyusu. Apabila bayi mendapatkan foremilk lebih banyak dibanding hindmilk dapat menimbulkan gassiness, ketidaknyamanan pada bayi, feses sering berwarna hijau, 
berair dan berbusa karena jumlah laktase tidak cukup memecah semua laktosa (Karatas et al, 2011).

Penelitian ini penting dilakukan karena memiliki urgensi yang tinggi yakni bayi sebagai penerus bangsa dan status kesehatan bayi juga menentukan derajat kesehatan suatu bangsa khususnya Indonesia sebagai negara berkembang (Maryunani, 2012). Desa Sukarende merupakan desa yang masih jauh dari perkotaan dan mayoritas ibu-ibu bekerja sebagai petani. Berdasarkan survei yang dilakukan pada bulan Maret 2019 terhadap 8 orang ibu menyusui di Desa Kampung Merdeka (berbatasan dengan Desa Sukarende), didapatkan 5 dari ibu yang menyusui secara eksklusif tidak pernah memantau pola defekasi bayinya dan 3 orang ibu lainnya menyusui secara eksklusif namun kadang feses bayi mereka berwarna hijau dan agak cair serta 6 kali buang air besar setiap hari.

Bayi harus mendapatkan nutrisi yang cukup dan seimbang dalam masa pertumbuhan dan perkembangannya agar bebas dari penyakit dan masalah yang kemungkinan dapat timbul. Penelitian ini juga dapat mendukung ibu agar mendukung ASI eksklusif dan menyusui yang benar pada bayi khususnya usia 1-6 bulan.

\section{METODE PENELITIAN}

Metode penelitian yang digunakan adalah kuantitatif dengan desain penelitian cross sectional. Jumlah sampe yang digunakan dalam penelitian ini sebanyak 30 orang, dengan teknik pengambilan sampel adalah total sampling, yaitu seluruh ibu yang memiliki bayi usia 1-6 bulan dan menyusui secara eksklusif., Teknik pengumpulan data menggunakan kuisioner dan observasi (Hidayat, 2011).

Tempat penelitian di Desa Sukarende pada bulan Mei sampai Juli 2019. Kuisioner tentang keseimbangan foremilk dan hindmilk terdiri dari 3 pertanyaan. Pertanyaan pertama tentang lama ibu menyusui bayi di setiap payudara, kedua kebiasaan ibu menyusui hingga payudara terasa kosong dan ketiga kebiasaan ibu membiarkan bayi menyusu pada satu payudara sampai habis dan baru dipindahkan ke payudara satunya apabila bayi masih menginginkannya. Apabila ibu menjawab ketiga pertanyaan tersebut dengan benar, maka dikategorikan seimbang, namun jika benar kurang dari 3 maka dikategorikan tidak seimbang. Lembar observasi untuk frekuensi defekasi $(<1$ kali sehari dan 1-8 kali sehari), konsistensi feses (cair atau padat dan lunak) dan warna feses bayi (kehijauan dan lain-lain, kuning). Dalam pengolahan data, dihitung jumlah frekuensi defekasi, konsistensi feses, 
Paninsari, D. dan Nurhayati, Eva. L. Pengaruh Keseimbangan Formilk dan Hindmilk dengan Pola Defekasi Bayi yang Mendapatkan ASI Eksklusif di Desa Sukarende

warna feses, keseimbangan foremilk dan Terdapat 16 ibu menyusui melakukan hindmilk serta pola defekasi bayi dengan keseimbangan foremilk dan hindmilk serta kategori normal (1) dan tidak normal (2). hanya 15 yang normal pola defekasi Analisis hasil penelitian dilakukan secara bayinya. Sedangkan sebanyak 14 orang bivariat dengan model statistik correlation ibu yang tidak melakukan keseimbangan (Kocaay et al, 2011).

\section{HASIL DAN PEMBAHASAN}

Bayi yang mendapatkan ASI eksklusif foremilk dan hindmilk, terdapat 11 bayi yang memiliki pola defekasi yang normal. Hasil penelitian dapat dilihat dari tabel dibawah ini.

di Desa Sukarende terdapat 30 orang.

Tabel 1. Distribusi Frekuensi Defekasi, Konsistensi dan Warna Feses

\begin{tabular}{cccccccccccc}
\hline & \multicolumn{3}{c}{ Frekuensi Defekasi } & \multicolumn{3}{c}{ Konsistensi } & \multicolumn{3}{c}{ Warna } \\
\hline \multicolumn{2}{c}{ <1x/hari } & \multicolumn{1}{c}{$1-8 \mathrm{x} /$ hari } & \multicolumn{2}{c}{ Cair/padat } & Lunak & Kehijauan/dll & Kuning \\
\hline $\mathrm{f}$ & $\%$ & $\mathrm{f}$ & $\%$ & $\mathrm{f}$ & $\%$ & $\mathrm{f}$ & $\%$ & $\mathrm{f}$ & $\%$ & $\mathrm{f}$ & $\%$ \\
1 & 3,3 & 29 & 96,7 & 1 & 3,3 & 29 & 96,7 & 2 & 6,7 & 28 & 93,3 \\
\hline
\end{tabular}

Berdasarkan tabel 1. diatas dapat mengetahui pengaruh keseimbangan dilihat bahwa mayoritas frekuensi defekasi foremilk dan hindmilk dengan pola 1-8 kali sehari (96,7\%), konsistensi feses defekasi. Hasil dapat dilihat dari tabel bayi lunak $(96,7 \%)$ dan warna feses bayi dibawah ini.

kuning (93,3\%).

Selanjutnya akan dilakukan analisa

bivariat dengan uji chi-square untuk

Tabel 2. Pengaruh Keseimbangan Foremilk dan Hindmilk dengan Pola Defekasi Bayi yang Mendapatkan ASI Eksklusif di Desa Sukarende

\begin{tabular}{|c|c|c|c|c|c|c|c|}
\hline \multirow{3}{*}{$\begin{array}{c}\text { Pola } \\
\text { Defekasi }\end{array}$} & \multicolumn{4}{|c|}{ Keseimbangan Foremilk dan Hindmilk } & \multicolumn{2}{|c|}{ Total } & \multirow[t]{2}{*}{ Pvalue } \\
\hline & \multicolumn{2}{|c|}{ Seimbang } & \multicolumn{2}{|c|}{ Tidak Seimbang } & & & \\
\hline & $\mathrm{f}$ & $\%$ & $\mathrm{f}$ & $\%$ & $\mathrm{f}$ & $\%$ & \\
\hline Normal & 15 & 93,75 & 11 & 78,57 & 26 & 86,66 & 0,222 \\
\hline $\begin{array}{c}\text { Tidak } \\
\text { Normal }\end{array}$ & 1 & 6,25 & 3 & 21,43 & 4 & 13,34 & \\
\hline Total & 16 & 100 & 14 & 100 & 30 & 100 & \\
\hline
\end{tabular}

Berdasarkan tabel diatas didapatkan tidak normal, 1 orang dari bayi tersebut bahwa dari 30 orang bayi ada $26(86,66 \%)$ bayi yang pola defekasinya normal, 15 mendapatkan foremilk dan hindmilk yang bayi mendapatkan foremilk dan hindmilk seimbang dan 3 bayi lainnya tidak mendapatkan foremilk dan hindmilk secara yang seimbang dan 11 bayi tidak seimbang. Sehingga, ada 16 bayi yang mendapatkan foremilk dan hindmilk yang mendapatkan keseimbangan foremilk dan seimbang. Sebanyak 4 orang bayi hindmilk sedangkan 14 bayi tidak $(13,34 \%)$ bayi memiliki pola defekasi mendapatkan foremilk dan hindmilk 
dengan seimbang. Pvalue didapatkan > $0,05,\left(\mathrm{H}_{0}\right.$ gagal ditolak), artinya tidak ada hubungan yang signifikan antara pengaruh keseimbangan foremilk dan hindmilk dengan pola defekasi bayi yang mendapatkan ASI Eksklusif di Desa Sukarende.

Hasil penelitian ini kurang sesuai dengan teori yang ada bahwa bayi yang tidak mendapatkan foremilk dan hindmilk secara seimbang setiap kali menyusu akan mengalami masalah pola defekasi, seperti frekuensi feses lebih dari 8 kali sehari (diare), konsistensi fesesnya cair dan warna feses bayi kehijauan karena adanya kandungan gas di feses tersebut. Dalam pembahasan pola defekasi dengan keseimbangan foremilk dan hindmilk ini masih cukup sulit dikarenakan informasi yang jarang ditemukan dan belum banyaknya penelitian tentang keseimbangan foremilk dan hindmilk (Sinujahi, 2009).

Menurut beberapa laporan penelitian, frekuensi dan konsistensi feses bayi dapat juga dipengaruhi oleh jenis makanan yang dikonsumsi oleh ibu serta jumlah makanan yang dikonsumsi tersebut. Misalnya, ibu mengkonsumsi makanan yang pedas dalam jumlah yang banyak dan dalam frekuensi sering, maka kandungan makanan pedas yang dikonsumsi ibu tersebut dapat mengakibatkan diare pada bayi. hal ini tentunya mengganggu pola defekasi bayi (Paninsari et al, 2017).

Keseimbangan foremilk dan hindmilk yang diukur dengan kuisioner didapatkan sebanyak 53,33\% ibu melakukan keseimbangan. Secara teori keseimbangan foremilk dan hindmilk didapatkan oleh bayi apabila ibu menyusui bayi hingga payudara terasa kosong dalam waktu bekisar >10 menit di setiap payudara (Mizuno et al., 2009).

Keseimbangan foremilk dan hindmilk yang tidak mempengaruhi pola defekasi berdasarkan hasil diatas dapat dipengaruhi oleh volume ASI ibu tersebut. Ibu yang memiliki volume ASI berlebihan atau sering disebut dengan hipergalaktia secara langsung volume laktosa juga akan dalam jumlah yang sangat banyak, sehingga bayi menyusui membutuhkan durasi yang lama untuk foremilk. Hal ini yang menyebabkan bayi kenyang dan tidak mau menyusu lagi sebelum mendapatkan hindmilk (Noble et al, 2009).

Durasi menyusui setiap bayi berbeda-beda sesuai dengan pola hisap bayi. Durasi menyusui berkaitan dengan adanya refleks prolaktin yang merupakan hormon laktogenik yang penting untuk memulai dan mempertahankan sekresi ASI. Jumlah prolaktin yang disekresikan berkaitan dengan besarnya stimulus isapan, termasuk frekuensi, intensitas dan 
Paninsari, D. dan Nurhayati, Eva. L. Pengaruh Keseimbangan Formilk dan Hindmilk dengan Pola Defekasi Bayi yang Mendapatkan ASI Eksklusif di Desa Sukarende

lama bayi mengisap (Purwani \& Darti, 2009).

Selanjutnya, pola defekasi pada bayi yang mendapatkan ASI eksklusif memiliki frekuensi defekasi 1-8 kali sehari. Namun, jika bayi buang air besar kurang lebih 3 hari sekali masih dalam kategori yang normal. Hal ini dikarenakan nutrisi yang masuk ke dalam usus bayi masih dalam bentuk cairan (ASI) sehingga sering terjadi penumpukan sisa-sisa ASI di dalam usus yang membutuhkan waktu beberapa hari untuk dikeluarkan. Pada keadaan ini, bayi tidak perlu diberikan obat-obatan, hanya cukup diberikan ASI saja (Tunc \& Camurdan, 2008).

\section{SIMPULAN}

Hasil penelitian menunjukkan bahwa tidak ada pengaruh keseimbangan foremilk dan hindmilk dengan pola defekasi bayi yang mendapatkan ASI eksklusif.

\section{UCAPAN TERIMA KASIH}

Peneliti mengucapkan terima kasih kepada: Kepala Desa dan seluruh masyarakat Desa Sukarende, yang sudah turut mendukung dalam penelitian ini. Universitas Prima Indonesia yang telah memberikan dukungan kepada peneliti. Spesial buat Ditjen DIKTI yang telah memberikan hibah PDP (Penelitian Dosen Pemula).

\section{DAFTAR PUSTAKA}

Hidayat, A. (2011). Metode Penelitian Kebidanan dan Teknik Analisis Data. Jakarta: Salemba Medika.

Karatas, Z., \& Aydogdu, S. D. (2011). Breastmilk ghrelin, leptin, and fat levels changing foremilk to hindmilk : is that important for self-control of feeding?, 1273-1280. https://doi.org/10.1007/soo431-011-1438-1

Kemenkes RI. (2017). Profil Kesehatan Indonesia Tahun 2017. Jakarta.

Kocaay, P., Tafi, Ö. E. R., \& Dalgiç, B. (2011). Normal defecation pattern, frequency of constipation and factors related to constipation in Turkish children o-6 years old, 2011(4), 369-375. https://doi.org/10.4318/tjg.2011.0238

Maryunani, A. (2012). Inisiasi Menyusui Dini, ASI Eksklusif dan Manajemen Laktasi. Jakarta: Trans Info Media.

Mizuno, K., Nishida, Y., Taki, M., Murase, M., Mukai, Y., Itabashi, K., ... Iiyama, A. (2009). Is increased fat content of hindmilk due to the size or the number of milk fat globules?, $\quad 6, \quad 2-7$. https://doi.org/10.1186/1746-4358-4-7

Noble, R., Bovey, A., Noble, R., \& Bovey, A. (2009). Resolution of Lactose Intolerance and Colic in Breastfed Babies.

Paninsari, D., Yantri, E., \& Yaunin, Y. (2017). Artikel Penelitian Hubungan Perilaku Ibu Menyusui dalam Keseimbangan Foremilk dan Hindmilk dengan Konsistensi Feses Bayi yang Mendapatkan ASI Eksklusif di Wilayah Kerja Puskesmas Andalas Padang, 3(1), 1-5.

Purwani, T., \& Darti, N. A. (2009). BAYI DI POLIKLINIK BERSALIN. Kebidanan, 6, 5. https://doi.org/1256872

Rochitasari N, Santoso B, P. N. (2011). Perbedaan Frekuensi Defekasi dan Konsistensi Tinja Bayi Sehat Usia o-4 Bulan yang Mendapat Asi Eksklusif, Non Eksklusif, dan Susu Formula. Sari Pediatri, 13(18), 191-199.

Sinujahi AB. (2009). Intoleransi Laktosa, 39(4), 424-429.

Tunc, V. T., \& Camurdan, A. D. (2008). Factors associated with defecation patterns, 13571362. https://doi.org/10.1007/soo431-0o80669-2

Uyan, Z. S., Özek, E., Bilgen, H., Cebeci, D., \& Akman, I. (2009). Effect of foremilk and hindmilk on simple procedural pain in newborns, 252-257.

Warsini, Aminingsih S, F. R. (2015). Hubungan antara jenis persalinan dengan keberhasilan asi eksklusif di kecamatan sukoharjo. Kosala, 3(2). 
BioLink : Jurnal Biologi Lingkungan, Industri dan Kesehatan, Vol.6 (2) (2020): hal. 146-152

West D. (2011). What is the difference between foremilk and hindmilk? Is my baby' $\mathrm{s}$ fussiness caused by the lactose in my milk? Breastfeeding, 5, 2. https://doi.org/104328 